\title{
ГАЗОХРОМАТОГРАФИЧЕСКОЕ ОПРЕДЕЛЕНИЕ СЛЕДОВЫХ КОЛИЧЕСТВ НЕКОТОРЫХ БЕНЗИЛОВЫХ И ФЕНИЛЭТИЛОВЫХ ЭФИРОВ 3-МЕТИЛ-5-АЛКОКСИ-2-ПЕНТЕН-1-ОЛОВ
}

A. ERM, Tatjana LIIV, Ilme LOIVEKE. MONEDE 3-METOUL-5-ALKOKSO-2-PENTEEN-1-OOLI BENSUOL- JA FENOULETOULEETRITE JÄLGEDE GAASIKROMATOGRAAFILINE MÄARAMINE

A. ERM, Tatyana LIIV, Ilme LOIVEKE. GLC DETERMINATION OF TRACEABLE AMOUNTS OF SOME BENZYL AND PHENYLETHYL ETHERS OF 3-METHYL-5-ALKOXY-2-PENTENE-1-OLS

\section{(Представил К. Лээтс)}

Полевые испытания аналогов ювенильного гормона (АЮГ) связаны с разработкой их оптимальных препаративных форм (ПФ), которые обычно готовят в виде эмульсионного концентрата или смачивающего порошка для равномерного распределения АЮГ после разбавления ПФ водой. Кроме того, ПФ АЮГ должны содержать примеси, увеличивающие стабильность и уменьшающие летучесть АЮГ. Для оценки эффективности ПФ АЮГ необходима методика определения следовых количеств АЮГ после экспонирования ПФ АЮГ в заданных условиях.

Нами предлагается методика газохроматографического определения следовых количеств $E$ - и $Z$-изомеров некоторых бензиловых и фенилэтиловых эфиров 3-метил-5-алкокси-2-пентен-1-олов, представляющих собой действующее вещество (ДВ) АЮГ, синтезированных в Институте химии АН ЭССР ['].

Экспериментальная часть. На полоски фильтровальной бумаги размером $10 \times 70$ мм наносили микропипеткой по 0,1 мл $0,2 \%$-ной эмульсия ПФ (3-метил-5-изопропокси) -2-пентенилфенилэтилового эфира в $\boldsymbol{H}$-гептане и выдерживали полоски на воздухе от 1 до 7 суток при комнатной температуре (или в других заданных условиях - напр., УФ-излучение, повышенная температура). Через каждые сутки (или через другой определенный промежуток времени) брали несколько полосок, разрезали на кусочки, помещали в отдельные пробирки и заливали раствором бензилбензоата («метка») объемом 0,5 мл в точно определенной концентрации $\left(1 \cdot 10^{-4}\right.$ г/мл). В зависимости от исследуемого АЮГ можно выбрать и другую «метку». Для контрольного опыта полоски фильтровальной бумаги (5 штук) сразу после высыхания эмульсии (около 20 мин) обрабатывали, как описано выше. Из полученных растворов после часовой выдержки и периодического взбалтывания брали микрошприцем пробы и хроматографировали. 
Условия хроматографирования:

Хроматограф «Хром 5» с ПИД

Длина колонки, м Диаметр колонки, мм Твердый носитель Хроматон N-AW-DMCS, MM

Жидкая фаза

Температура колонки, ${ }^{\circ} \mathrm{C}$

Температура испарителя, ${ }^{\circ} \mathrm{C}$

Расход газов, мл/мин:

азота

водорода

воздуха

\section{2,5}

3

$0,16-0,20$

$5 \%$ XE-60

190

250

300
Скорость диаграммной ленты, см/мин $\quad 0,6$

Рабочая шкала электрометра, А

$5 \cdot 10^{-11}$

Объем вводимой пробы, мкл

2

Времена удерживания

(3-метил-5-изопропокси) -2-пентенилфенилэтилового эфира, мин

$Z$-изомера

$E$-изомера

бензилбензоата

Обработка результатов. Остаточную долю ДВ АЮГ в ПФ $\left(C_{\text {ост }}\right)$ вычисляли по формуле

$$
C_{\text {ост }}=\frac{X_{\mathrm{K}}}{X_{\mathrm{H}}} \cdot 100 \% \text {, }
$$

где $X_{\text {н }}$ и $X_{\mathrm{F}}$ - средние соотношения суммы площадей пиков $E$ - и $Z$-изомеров АЮГ к площади пика бензилбензоата $\left(S_{E}+S_{Z}\right) / S_{B}$ в начальной и конечной пробах. Расхождение этих значений не должно превышать $5 \%$.

Зная концентрацию ДВ АЮГ в ПФ, можно вычислить следовое количество ДВ на одной полоске бумаги. Предел обнаружения ДВ в анализируемой пробе - 0,005 мкг/мл экстракта.

\section{Л И ТЕ Р А Т У Р А}

1. Лээтс К., Шмидт М., Каал T., Куузик А., Вялимяэ Т. Синтез аналогов ювенильного гормона. 8. Получение и ювенильная активность некоторых бензиловых и фенилэтиловых эфиров 3-метил-5-алкокси-2-пентен-1-олов, - Изв. АН ЭССР. Хим., 1986,35 , № $3,223-225$.

Ннститут химии

Академии наук Эстонской ССР
Поступила в редакцию 20/XI 1987 